\title{
Evidence of Multiple Sources of Soil Gas in the Tangshan Fault Zone, North China
}

\author{
Zhi Chen $\mathbb{D}^{1},{ }^{1}$ Ying Li $\left(\mathbb{D},{ }^{1}\right.$ Zhaofei Liu $\mathbb{D},{ }^{1}$ Chang Lu, ${ }^{1}$ Yuanxin Zhao, ${ }^{1}$ and Jiang Wang ${ }^{2}$ \\ ${ }^{1}$ CEA Key Laboratory of Earthquake Prediction (Institute of Earthquake Forecasting), China Earthquake Administration, \\ 63 Fuxing Road, Haidian District, Beijing 100036, China \\ ${ }^{2}$ Hebei Earthquake Agency, Shijiazhuang 050022, China
}

Correspondence should be addressed to Ying Li; subduction6@hotmail.com

Received 20 May 2019; Revised 11 July 2019; Accepted 5 August 2019; Published 12 September 2019

Academic Editor: Andrea Brogi

Copyright (C) 2019 Zhi Chen et al. This is an open access article distributed under the Creative Commons Attribution License, which permits unrestricted use, distribution, and reproduction in any medium, provided the original work is properly cited.

\begin{abstract}
The sources of soil gases in the Tangshan fault zone, North China, were discussed, based on the soil gas compositions and isotopic ratios obtained by measurement in the field and sample analysis in the laboratory. Soil gas compositions and isotopic ratios indicate that $\operatorname{air}(\mathrm{A})$ end-member, limestone (L) end-member, and sediment $(\mathrm{S})$ end-member are the major end-member components contributing to the soil gas in our study area, with fractional contributions in the range of $2-15 \mathrm{vol} . \%, 23-36 \mathrm{vol} . \%$, and 62-65 vol.\%, respectively, to $\mathrm{CO}_{2}$ from the gas wells. According to the relationship among the ${ }^{3} \mathrm{He} /{ }^{4} \mathrm{He}$, average $\mathrm{CO}_{2}$ concentration, and $\mathrm{He}$ concentration of soil gas, the deepest depth the fault cut downward and the most developed fractures in the segment where the Heibeiligong (HBLG) well located were inferred, and the shallower depth the fault cut downward and the more developed fractures in the fault segments where the Weifengshan (WFS), Siwangzhuang (SWZ), Tianjingyice (TJYC), and Douhetai (DHT) wells located were inferred. Significant variations in $\mathrm{CO}_{2}$ concentration were observed in soil gases sampled in DHT, HBLG, and WFS soil gas wells in concomitance with a local seismic sequence by 2018 confirming for the first time a possible source of carbon dioxide generated in underlying limestones.
\end{abstract}

\section{Introduction}

Earthquakes are caused by tectonic evolution accompanied by matter and energy exchange deep inside the earth [1-3], which is mainly transmitted by fluid being released through active faults and fractures at different depths [4], owing to that fault and fracture are preferential migration pathways for gases $\left(\mathrm{CO}_{2}, \mathrm{Rn}, \mathrm{He}\right.$, etc.) in the deep crust to migrate upward to the surface, due to their enhanced permeability and porosity relative to the surrounding rocks [5-7]. General overviews of the geochemical, structural, and seismic features in tectonically active areas have shown some evidence of correlation between soil gas geochemistry anomalies and tectonic activities, and soil gas discharge through fault and fracture in the active fault zones can be enhanced by fault and earthquake activity (Wakita et al., 1980; Toutain et al., 1992; [8-11]). As such, analyzing the origins and geochemical variations of soil gas in the seismically active areas could be a potential way to study faults and seismic activity
[12-14]. At present, soil gas concentration and flux surveys along active fault zones have been widely undertaken for earthquake research and prediction (Caracausi et al., 2003; [11, 15]).

Recent studies of soil gas geochemistry within fault zones and its relationship with earthquake activity further indicate that it can potentially be used to monitor earthquakes $[10,11$, $16,17]$. Soil gas geochemical surveys in seismically active areas have been carried out across the world $[5,6,18,19]$, and some anomalies appearing before earthquakes have been identified $[11,20]$. In the Arax Basin (Armenia), radon volume activities have been observed to vary before and after earthquakes [21]. Similarly, anomalously high radon volume activity fluctuations were observed several hours to a few days before an earthquake $\left(M_{L}>3\right)$ that occurred in northern Taiwan [7].

Soil gas anomalies are usually complex as they are subject to multiple influences (atmospheric, biogenic, organic, and from the deep crust and mantle; [11,22-24]) and occasionally 
their relationships with seismic events may be ambiguous $[4,7,25,26]$. Accordingly, if the observation of soil gas in fault zones is to become a useful method of fault activity assessment and seismic forecasting, further analysis of their relationships is required and the source identification for soil gas in the seismically active areas is a prerequisite.

The Tangshan fault is the main shock fault in which occurred the 1976 Tangshan $M_{S} 7.8$ earthquake, one of the most destructive earthquakes ever recorded and caused 240000 deaths and property losses of over \$ 1.4 billion [27]. In this region, earthquakes have occurred with increasing frequency (more than 20 earthquakes of $\mathrm{M}_{\mathrm{S}} \geqq 3.0$ per year since 2016) and high concentrations of soil gas components have been observed $[5,28]$.

In the present study, we aim to (1) investigate the origins of soil gas emitted from the Tangshan fault zone based on gas compositions and isotope ratio values, (2) analyze correlations between variations of soil gas component concentrations and earthquakes in the Tangshan fault zone, and (3) identify methods and components that are potential for earthquake monitoring in the Tangshan area of Northern China.

\section{Geological Setting}

The Tangshan fault zone is located in a fold depression region where the Northern China and Yanshan uplifts converge. It is considered to be a strain accumulation structure comprising three active faults, which are as follows, from north to south: Douhe fault $\left(\mathrm{F}_{1}\right)$, Weishan-Changshan fault $\left(\mathrm{F}_{2}\right)$, and Tangshan-Guye fault $\left(\mathrm{F}_{3}\right)$. All three are normal faults with right lateral strike-slip and have NE trending $\left(25-35^{\circ}\right)$ and NW dipping with high dip angles (70-80 ; Liu et al., 2011). The 1976 Tangshan $\mathrm{M}_{\mathrm{S}} 7.8$ earthquake occurred in the middle segment of the Tangshan fault zone and was followed by 54 aftershocks of $M_{S} \geqq 5.0$ (Figure 1). This was interpreted as a complex tectonic process of strike-slip, thrust, and normal-fault events caused by detachment, fault propagation in the middle crust, and stress accumulation in the base of the upper crust [14].

The basement of the Tangshan area is composed of preSinian metamorphic rocks with varying metamorphic grades whose outcrops rarely occur in the study area covered by the thick sediments of the Holocene $\left(\mathrm{Q}_{4}\right)$ and upper Pleistocene $\left(\mathrm{Q}_{3}\right)$, but Ordovician, Cambrian, and Proterozoic strata consisting mainly of limestone are widely exposed in the northern segment of the Tangshan fault zone, with $\delta^{13} \mathrm{C}$ (PDB) and $\delta^{18} \mathrm{O}(\mathrm{PDB})$ in the range of $-0.65-1.40 \%$ and $-12.34-7.47 \%$, respectively [29]; Mesozoic and Tertiary sediments are missing in the study area, and the thickness of Pleistocene and Holocene sediments increases from about $100 \mathrm{~m}$ in the north to $800 \mathrm{~m}$ in the south $[14,30,31]$. The total carbon contents of soil in the northern and southern segments of the Tangshan fault zone were $1.63 \%$ and $0.85 \%$, respectively, and the $\mathrm{Ra}$ contents were $27.2 \mathrm{~Bq} \mathrm{~kg}^{-1}$ and $20.4 \mathrm{~Bq} \mathrm{~kg}^{-1}$, respectively [32]. Geological, seismic, and electrical surveys show that the active faults have dislocated the strata of the Cenozoic Era [14, 33]. The target area for the soil gas measurement in the field was about $2100 \mathrm{~km}$, with

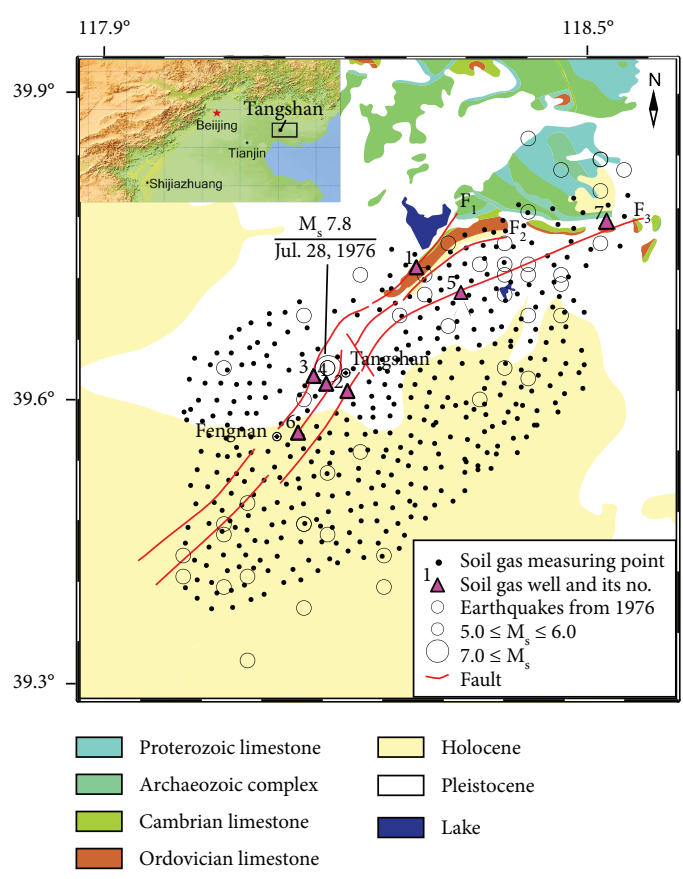

FIgURE 1: A map of the study area, with inset showing its location in NE China. $F_{1}$ : Douhe fault; $F_{2}$ : Weishan-Tangshan fault; $F_{3}$ : Tangshan-Guye fault.

the length of about $70 \mathrm{~km}$ and width of about $30 \mathrm{~km}$, covered the three active faults and seven soil gas wells (Figure 1).

\section{Methods}

3.1. Soil Gas Measurements. Soil gas measurements were performed in the field at 388 measurement points covering the Tangshan fault zone (Figure 1). The $\mathrm{CO}_{2}$ concentration and $\mathrm{Rn}$ (radon) activity were measured at approximately $1-1.5 \mathrm{~km}$ intervals between every two measurement points. In order to avoid possible meteorological effects on the soil gas concentrations (Hinkle, 1994), the soil gas survey was carried out during a period of stable meteorological conditions from 8 April to 7 May 2010. At this time (spring), the air temperature (mean $=7.1-19.6^{\circ} \mathrm{C}$ ) and wind velocity $\left(\right.$ mean $=3-5 \mathrm{~m} \mathrm{~s}^{-1}$ ) remain relatively stable and the mean rainfall over the study period (approximately 1 month) is $21.3 \mathrm{~mm}$, which is relatively low given that the mean monthly rainfall for the Tangshan area is $50 \mathrm{~mm}$ (http://data.cma.cn). The $\mathrm{CO}_{2}$ concentrations and $\mathrm{Rn}$ volume activity were measured by inserting a stainless steel sampling tube with a $3 \mathrm{~cm}$ diameter into the ground to a depth of $0.8 \mathrm{~m} \mathrm{[34].} \mathrm{The}$ sampling tube was connected by rubber tubes to a radon detector ( $\mathrm{RAD} 7$, for Rn volume activity) and a portable infrared $\mathrm{CO}_{2}$ monitor (GXH-3010-E, for $\mathrm{CO}_{2}$ concentration; Figure 2). Rn activity was measured $15 \mathrm{~min}$ after sampling (the time necessary for Po and Rn nuclei to reach equilibrium, which is about five times the half-life of $\left.{ }^{218} \mathrm{Po}\right)$. The detection limit and measurement error of the RAD 7 radon detector were $3.7 \mathrm{~Bq} \mathrm{~m}^{-3}$ and $\pm 5 \%$, respectively. An inlet filter and molecular sieve were used to protect the detector from dust and soil moisture. The detection limit and measurement 


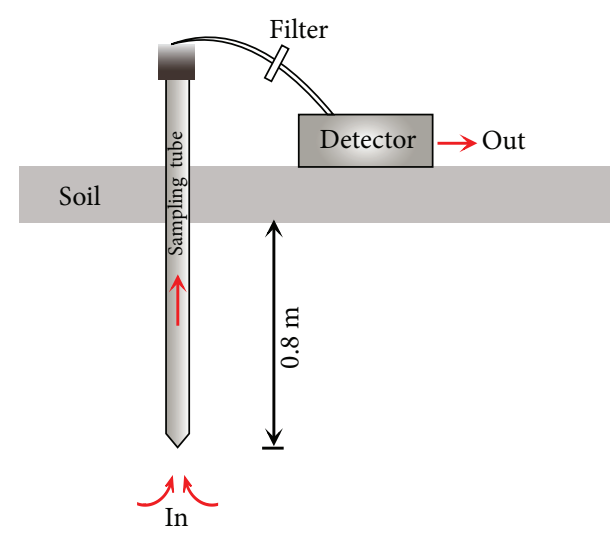

Figure 2: Sketches of the methods used for soil gas measurement at the mobile measurement points.

error of the GXH 3010-E $\mathrm{CO}_{2}$ monitor were $0.01 \%$ and $\pm 2 \%$, respectively. An inlet filter was used to protect the detector from dust.

3.2. Soil Gas Measurement in Selected Wells. Seven sites were selected for soil gas measurements and equipped with shallow depth wells in November 2017 (Figure 1). These sites were selected because they are characterized by (1) relatively high $\mathrm{CO}_{2}$ concentration and $\mathrm{Rn}$ activity, (2) distance $<2.0 \mathrm{~km}$ from the fault, and (3) a lack of possible artificial sources of contamination. An inverted polytetrafluoroethylene (PTFE) circular accumulation hemispherical chamber with a volume of $1.68 \times 10^{-2} \mathrm{~m}^{3}$ and a radius of $0.2 \mathrm{~m}$ was fixed $5.0 \mathrm{~m}$ below the ground. A 6-channel deconcentrator was installed on the inner wall of the chamber to reinject the circulating gas in order to ensure the immediate and homogeneous mixture of gas in the chamber. Two exhaust tubes (PTFE, $5.0 \mathrm{~m}$ in length, $10 \mathrm{~cm}$ in diameter) were used, with their lower ends connected to the top of the chamber and their other ends connected to the inlet and outlet of the detector. These devices form a closed circuit for the analysis of gases present in the first five meters of sediments (Figure 3). Gas measurements were performed repeatedly in the field at the end of each month from June to November 2018. Gas samples were also collected from the outlet of the apparatus following the methods described by Chen et al. [5] and Zhang et al. [35] in September 2018.

3.3. Laboratory Analysis. Gas compositions $\left(\mathrm{CO}_{2}, \mathrm{CH}_{4}, \mathrm{Ar}\right.$, $\mathrm{H}_{2} \mathrm{~S}, \mathrm{~N}_{2}$, and $\left.\mathrm{O}_{2}\right)$ and isotopic ratios $\left(\delta^{13} \mathrm{C}_{\mathrm{CO}_{2}},{ }^{3} \mathrm{He} /{ }^{4} \mathrm{He}\right.$ $(\mathrm{R} / \mathrm{Ra}), \mathrm{CO}_{2} /{ }^{3} \mathrm{He}$, and $\left.{ }^{4} \mathrm{He} /{ }^{20} \mathrm{Ne}\right)$ were all measured in the Laboratory of Gas Geochemistry (Lanzhou, China), Institute of Geology and Geophysics, Chinese Academy of Sciences. Gas compositions were determined by a mass spectrometer (MAT 271) and characterized by relative standard deviations of $<5 \%$. The ${ }^{3} \mathrm{He} /{ }^{4} \mathrm{He}$ (reported as $\mathrm{R} / \mathrm{Ra}, \mathrm{Ra}=1.4 \times 10^{-6}$ ) and ${ }^{4} \mathrm{He} /{ }^{20} \mathrm{Ne}$ values were determined by a different mass spectrometer (VG 5400), while $\delta^{13} \mathrm{C}$ values were analyzed by a gas chromatography-pyrolysis-isotope ratio mass spectrometer (HP 6890-Delta Plus XL) with uncertainties of $\pm 0.3 \%$. Analysis of all the samples was completed from
December 5 to December 7, 2018, within 10 days of sampling. Air on the Gaolan Hill in the south of Lanzhou was used to calibrate the instrument [35].

3.4. Population Identification and Spatial Distribution Analysis. The graphical statistical method (GSA) of Sinclair [36] was used as described by Chiodini et al. [22] to distinguish different populations of soil gas from the Tangshan fault zone. This method involves plotting $\mathrm{CO}_{2}$ concentrations or Rn volume activity values against a cumulative probability and identifying inflection points within each dataset. The inflection points signify partitions among different statistical populations, which may represent discrete sources of soil gas [37]. The data obtained at the mobile measurement points were processed using the Kriging interpolation method in the SURFER 8.0 package; then, the contour maps were built with the data set to analyze the spatial distributions of $\mathrm{CO}_{2}$ concentrations and $\mathrm{Rn}$ volume activity. Kriging is a general approach for stochastic spatial interpolation in which the continuous regionalized variable of interest $Z(s)$, sometimes referred to as the primary variable, is predicted at any unsampled location $s$ of the study area $D$ using the values of $Z$ measured at different locations; $Z\left(s_{i}\right), i=1, \cdots, n$, the predicted value at location $s, Z(s)$, is calculated as an affine linear combination of the $n$ observed values in such a way that it is a best linear unbiased prediction predictor [38].

\section{Results}

The $\mathrm{CO}_{2}$ concentrations and $\mathrm{Rn}$ activities obtained at the 388 measurement points were in the ranges of 514.0$10318.1 \mathrm{ppm}$ and $882.4-17283.5 \mathrm{~Bq} \mathrm{~m}^{-3}$, respectively, with means of $2438.6 \mathrm{ppm}$ and $4730.5 \mathrm{~Bq} \mathrm{~m}^{-3}$, respectively (Table 1).

The geochemical parameters of soil gases sampled in the seven shallow depth wells (DHT, TJYC, HBLG, LHD (Luhuadai), HET (Haiertun), SWZ, and WFS) in the Tangshan fault zone are listed in Table 2. The concentrations of $\mathrm{CO}_{2}, \mathrm{CH}_{4}, \mathrm{Ar}, \mathrm{H}_{2} \mathrm{~S}, \mathrm{~N}_{2}$, and $\mathrm{O}_{2}$ in soil gas sampled in the seven constructed shallow depth wells were in the ranges of 0.09-6.23\%, 31-113 ppm, 0.92-1.15\%, 0-631 ppm, 78.64$97.81 \%$, and $0.45-19.90 \%$, respectively. The Rn volume activities were in the ranges of $4.59-33.00 \mathrm{kBq} \mathrm{m}^{-3}$. The atmospheric concentrations of $\mathrm{CO}_{2}$ and $\mathrm{He}$ in the study area were $0.04 \%$ and $5.35 \mathrm{ppm}$, respectively.

The ${ }^{3} \mathrm{He} /{ }^{4} \mathrm{He}(\mathrm{R} / \mathrm{Ra}), \mathrm{CO}_{2} /{ }^{3} \mathrm{He}$, and ${ }^{4} \mathrm{He} /{ }^{20} \mathrm{Ne}$ ratios of soil gas sampled in the seven shallow depth wells varied from 0.99 to $1.13,3.68 \times 10^{8}$ to $3.18 \times 10^{9}$, and 0.28 to 0.31 , respectively. The $\delta^{13} \mathrm{C}$ values of $\mathrm{CO}_{2}$ were in the range of -19.9 to $-18.9 \%$. The ${ }^{3} \mathrm{He} /{ }^{4} \mathrm{He}(\mathrm{R} / \mathrm{Ra}), \delta^{13} \mathrm{C}_{\mathrm{CO}_{2}}, \mathrm{CO}_{2} /{ }^{3} \mathrm{He}$, and ${ }^{4} \mathrm{He} /{ }^{20} \mathrm{Ne}$ ratios of air in the study area were $0.99,-8.3 \%$, $5.40 \times 10^{7}$, and 0.29 , respectively (Table 2 ).

\section{Discussion}

5.1. Sources of Soil Gas Sampled in the Tangshan Fault Zone. The probability plots of both $\mathrm{CO}_{2}$ concentration and $\mathrm{Rn}$ activity of soil gas collected at the 388 sampling points displayed three-segment distributions, characterized by the 


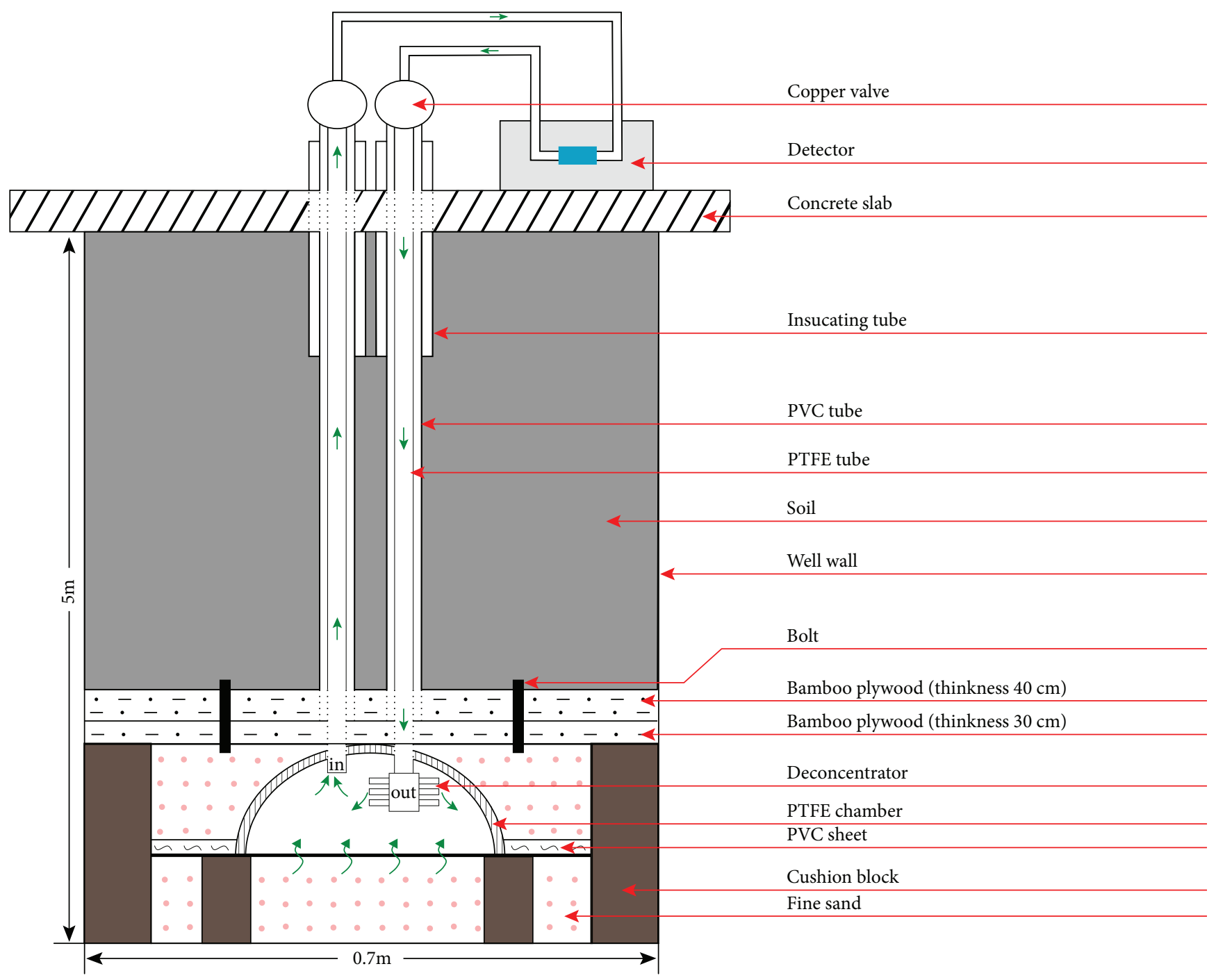

Figure 3: A sketch of the constructed soil gas well.

TABle 1: $\mathrm{CO}_{2}$ concentrations and $\mathrm{Rn}$ activities in soil sampling points.

\begin{tabular}{lccccc}
\hline Gas component & No. & Mean & Min & Max & $\begin{array}{r}\text { Standard } \\
\text { deviation }\end{array}$ \\
\hline $\mathrm{Rn}\left(\mathrm{Bq} \mathrm{m}^{-3}\right)$ & 388 & 4730.5 & 882.4 & 17283.5 & 3465.3 \\
$\mathrm{CO}_{2}(\mathrm{ppm})$ & 388 & 2438.6 & 514.0 & 10318.1 & 2068.0 \\
\hline
\end{tabular}

partial overlap of a low population (A), a medium population (B), and a high population (C; Figures 4 and 5). There were two inflection points at $\mathrm{CO}_{2}$ concentrations of $3692 \mathrm{ppm}$ and $8269 \mathrm{ppm}$, indicated by arrows in the figures, which delineate the fractions of $80 \%$ for Population A, $16 \%$ for Population B, and 4\% for Population C (Figure 4). There were also two inflection points at $\mathrm{Rn}$ volume activities of $7588.2 \mathrm{~Bq} \mathrm{~m}^{-3}$ and $13749.8 \mathrm{~Bq} \mathrm{~m}^{-3}$, delineating the fractions of $83 \%$ for Population A, $12 \%$ for Population B, and $5 \%$ for Population C (Figure 5). The means and 95\% confidence intervals of $\mathrm{CO}_{2}$ concentration and $\mathrm{Rn}$ volume activity and the fractions of the three populations listed in Table 3 were determined using the GSA method [39].

Contour maps of soil gas $\mathrm{CO}_{2}$ concentrations and of $\mathrm{Rn}$ activities found in the 388 mobile measurement points were mapped in Figures 4 and 5. A consistent spatial coincidence of $\mathrm{CO}_{2}$ concentrations and of $\mathrm{Rn}$ activities was found (Figures 6 and 7), which may indicate common sources of $\mathrm{CO}_{2}$ and $\mathrm{Rn}$, as $\mathrm{CO}_{2}$ can act as a carrier gas for $\mathrm{Rn}[4,40]$. In addition, almost all the $\mathrm{CO}_{2}$ and $\mathrm{Rn}$ values from Population $\mathrm{C}$ are concentrated near the fault zone; in contrast, almost all $\mathrm{CO}_{2}$ and $\mathrm{Rn}$ values from Population $\mathrm{A}$ are distributed outside the fault zone. Moreover, most of the $\mathrm{CO}_{2}$ and $\mathrm{Rn}$ values from Population B are located near the fault zone but with some outside it (Figures 6 and 7). Gases migrating from deep geological formations towards the surface through faults are usually characterized by enrichment in one or more components compared to atmospheric composition and are expected in fault zones. Outside the fault zones, gases are diffused in the superficial soil and show lower concentrations 


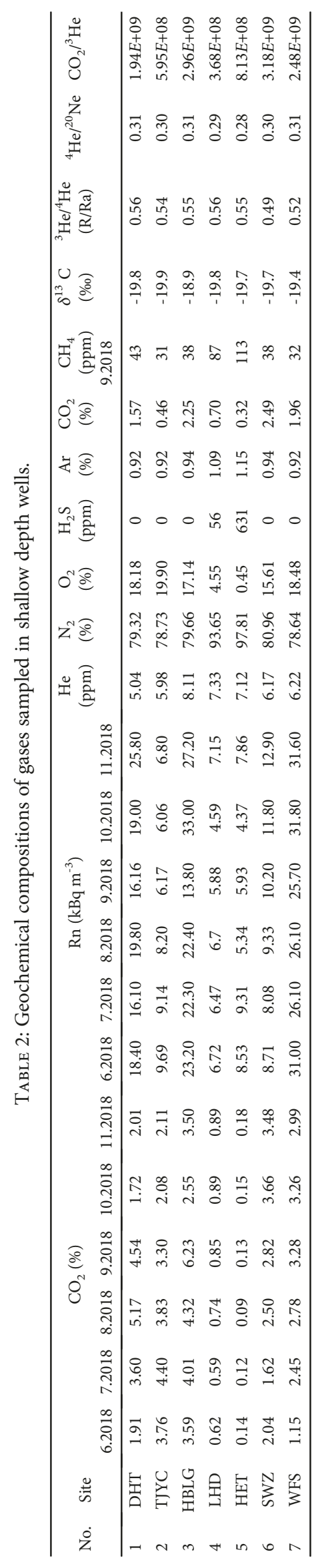




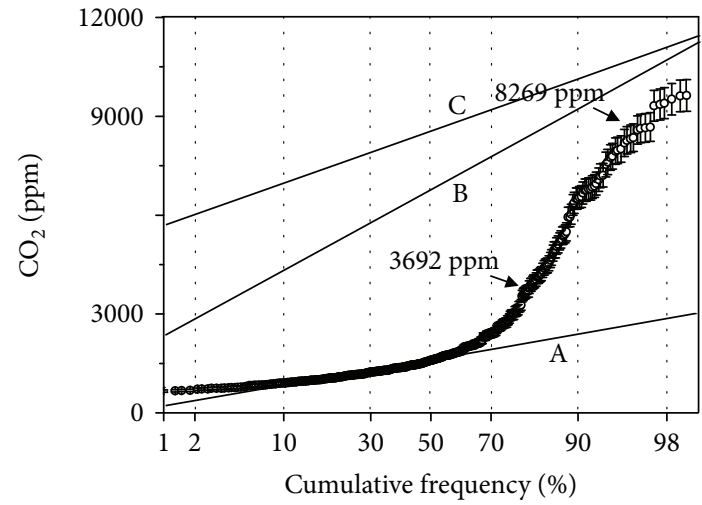

FIgure 4: Probability plots of soil gas $\mathrm{CO}_{2}$ concentrations in the 388 sampling points.

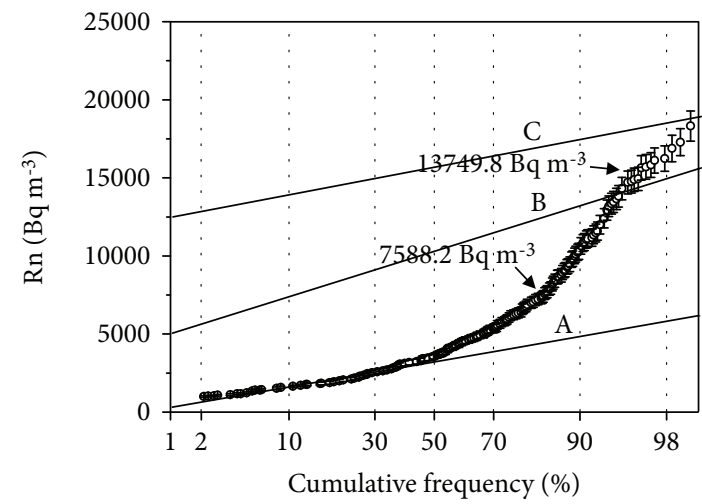

Figure 5: Probability plots of soil gas Rn activities in the 388 sampling points.

of nonatmospheric components [41-43]. Hence, it could be inferred that the $\mathrm{CO}_{2}$ and $\mathrm{Rn}$ of Population A come from the superficial soil, while those of Population $\mathrm{C}$ uprise from deeper locations through faults. Meanwhile, the $\mathrm{CO}_{2}$ and Rn of Population B could have a complex source due to biogenic, thermogenic, mechanochemical, or rock weathering origins $[9,44-46]$. Accordingly, further investigations into eventual geochemical variations over time should be carried out chiefly in soil gases from Population $\mathrm{C}$ since they are more representative of the deep originating component.

Therefore, attention has been focused on identifying the origin of soil gases of Population C and seven soil gas wells with depths of $5.0 \mathrm{~m}$ were constructed along faults in November 2017 for soil gas measurement and sampling (Figures 1 and 3).

As shown in Tables 1 and 2, the $\mathrm{CO}_{2}$ concentrations $(0.12-6.23 \%)$ and $\mathrm{Rn}$ activities $\left(4.59-33.00 \mathrm{kBq} \mathrm{m}^{-3}\right)$ of soil gas from the seven soil gas wells were much higher than those from the 388 mobile measurement points (514.0-10318.1 ppm for $\mathrm{CO}_{2}$ concentration and $882.4-17283.5 \mathrm{~Bq} \mathrm{~m}^{-3}$ for Rn volume activity), suggesting that the new wells were relatively less exposed to dilution processes of gases by the superficial soil gas and by the atmosphere.
The results of the total gas component analysis showed that the major chemical species of the soil gas samples were $\mathrm{N}_{2}, \mathrm{O}_{2}, \mathrm{CO}_{2}$, and Ar. The He concentrations in the soil gas samples from the well were slightly higher than those of the atmosphere except for that of DHT (Table 2), according to the results of ${ }^{3} \mathrm{He} /{ }^{4} \mathrm{He}(\mathrm{R} / \mathrm{Ra})$ and ${ }^{4} \mathrm{He} /{ }^{20} \mathrm{Ne}$ analyses (Figure 8), which could indicate the minority contribution of gases upwelling from the deep earth to the soil gases of the Tangshan fault, although the soil gases could mainly derive from the atmosphere.

However, the $\mathrm{CO}_{2}$ concentrations of gas samples from the seven new soil gas wells were much higher than the atmospheric concentration (Table 2), suggesting that there were other sources of $\mathrm{CO}_{2}$. As reported in previous studies, underground $\mathrm{CO}_{2}$ is a crucial link in the interactions among gas, water, rocks, and biological activities [46]. The two main origins of underground $\mathrm{CO}_{2}$ are the microbial degradation of organic matter in sediment and limestone weathering, including water-limestone interactions and limestone decomposition $[44,45,47,48]$. Thus, an approach analogous to that used for the identification and quantification of $\mathrm{CO}_{2}$ in volcanic and geothermal regions was adopted $[35,49,50]$. The mantle $(\mathrm{M})$ end-member was replaced with an air (A) end-member (Figure 9); then, three major endmember components involving an air (A) end-member, limestone (L) end-member, and sediment $(\mathrm{S})$ end-member were selected to identify and quantify the various sources contributing to $\mathrm{CO}_{2}$ from the seven new wells. The $\delta^{13} \mathrm{C}$ value of $-8.3 \%$ and the $\mathrm{CO}_{2} /{ }^{3} \mathrm{He}$ ratio of $5.4 \times 10^{7}$ for the (A) end-member were obtained by measuring air samples (Table 1). For the (L) and (S) end-members, $\delta^{13} \mathrm{C}$ values of $0 \%$ and $-30 \%$, respectively, with a corresponding $\mathrm{CO}_{2} /{ }^{3} \mathrm{He}$ ratio of $1.0 \times 10^{13}$, were suggested by Sano and Marty [49]. The fractions contributed by the (A), (L), and (S) end-members to the $\mathrm{CO}_{2}$ at the seven new wells were estimated using the following mass balance equations:

$$
\begin{aligned}
& \left({ }^{13} \mathrm{C} /{ }^{12} \mathrm{C}\right)_{o}=f_{\mathrm{A}}\left({ }^{13} \mathrm{C} /{ }^{12} \mathrm{C}\right)_{\mathrm{A}}+f_{\mathrm{L}}\left({ }^{13} \mathrm{C} /{ }^{12} \mathrm{C}\right)_{\mathrm{L}}+f_{\mathrm{S}}\left({ }^{13} \mathrm{C} /{ }^{12} \mathrm{C}\right)_{\mathrm{S}}, \\
& \frac{1}{\left(\mathrm{CO}_{2} /{ }^{3} \mathrm{He}\right)_{o}}=\frac{f_{\mathrm{A}}}{\left(\mathrm{CO}_{2} /{ }^{3} \mathrm{He}\right)_{\mathrm{A}}}+\frac{f_{\mathrm{L}}}{\left(\mathrm{CO}_{2} /{ }^{3} \mathrm{He}\right)_{\mathrm{L}}}+\frac{f_{\mathrm{L}}}{\left(\mathrm{CO}_{2} /{ }^{3} \mathrm{He}\right)_{\mathrm{S}}}, \\
& f_{\mathrm{A}}+f_{\mathrm{L}}+f_{\mathrm{s}}=1,
\end{aligned}
$$

where $o=$ observed, and $\mathrm{f}$ is the fraction contributed by the (A), (L), and (S) end-members to the $\mathrm{CO}_{2}$ at the seven soil gas wells.

The results showed that $62-65 \%$ of the $\mathrm{CO}_{2}$ from the seven wells was derived from the (S) end-member, $23-36 \%$ was derived from the (L) end-member, and the remaining $2-15 \%$ came from the (A) end-member (Figure 9 and Table 4).

This suggests that the major sources of $\mathrm{CO}_{2}$ in the Tangshan fault zone are the microbial degradation of organic matter and the decomposition of carbonatic rocks in sediments. Furthermore, the higher $\mathrm{N}_{2} / \mathrm{O}_{2}$ ratios, together with the strong correlation between the depleted $\mathrm{O}_{2}$ concentrations (compared to the atmosphere) and the $\mathrm{CO}_{2}$ concentrations 
TABLE 3: Statistical parameters of partitioned $\mathrm{CO}_{2}$ concentrations and $\mathrm{Rn}$ volume activities at the mobile measurement points.

\begin{tabular}{|c|c|c|c|c|c|c|}
\hline \multirow{2}{*}{ Population } & \multicolumn{2}{|c|}{ Fraction } & Mean concentration & \multirow{2}{*}{$\begin{array}{l}\text { 95\% confidence interval } \\
(\mathrm{ppm})\end{array}$} & \multirow{2}{*}{ Mean activity } & \multirow{2}{*}{$\begin{array}{l}\text { 95\% confidence interval } \\
\mathrm{Rn}\left(\mathrm{Bq} \mathrm{m}^{-3}\right)\end{array}$} \\
\hline & $\mathrm{CO}_{2}$ & $\mathrm{Rn}$ & & & & \\
\hline Population A & 0.80 & 0.83 & 1513 & $1491-1643$ & 3894.1 & $3549.0-4240.2$ \\
\hline Population B & 0.16 & 0.12 & 5415 & 5396-6109 & 10229.0 & $9655.5-10803.0$ \\
\hline Population C & 0.04 & 0.05 & 8893 & 8679-9328 & 15471.0 & $14861.0-16082.0$ \\
\hline
\end{tabular}

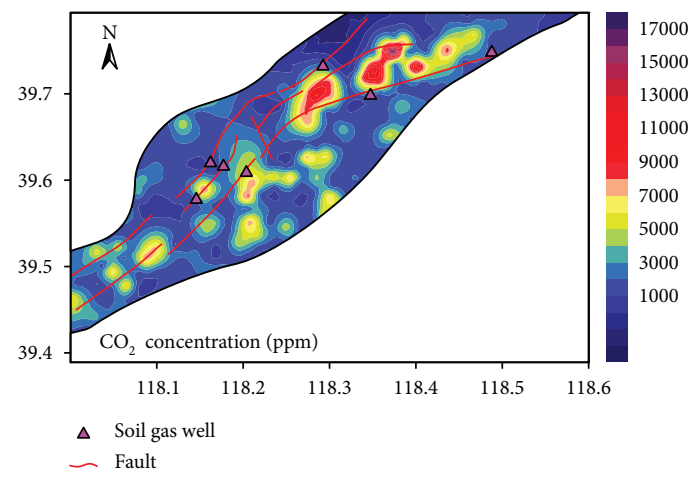

Figure 6: A contour map of soil gas $\mathrm{CO}_{2}$ concentrations in the 388 sampling points.

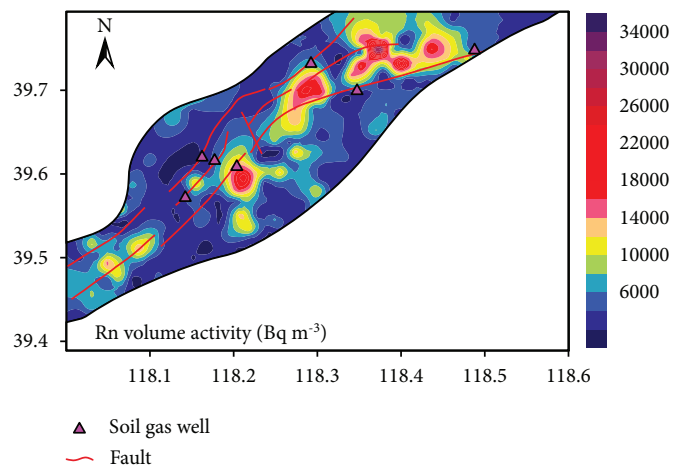

FIGURE 7: A contour map of soil gas Rn volume activities in the 388 sampling points.

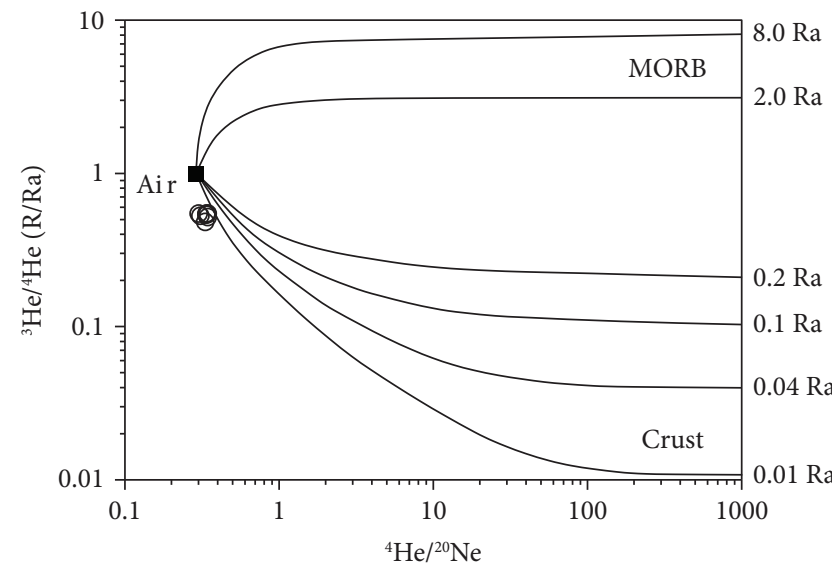

O Values of this study

Figure 8: Plots showing ${ }^{3} \mathrm{He} /{ }^{4} \mathrm{He}(\mathrm{R} / \mathrm{Ra})$ versus ${ }^{4} \mathrm{He} /{ }^{20} \mathrm{Ne}$ values for gas samples from the seven soil gas wells.

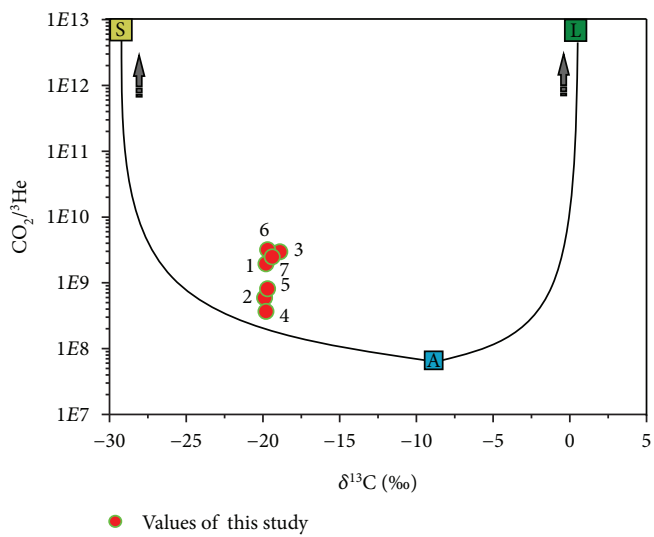

Figure 9: Plot showing $\mathrm{CO}_{2} /{ }^{3} \mathrm{He}$ versus $\delta^{13} \mathrm{C}$ values for gas samples from the shallow depth wells. A: air end-member; L: limestone end-member; S: sediment end-member.

TABLE 4: Fractional $\mathrm{CO}_{2}$ contributions by different end-members to the soil gases.

\begin{tabular}{lccc}
\hline Site & $\begin{array}{c}\text { Proportions of } \\
\text { A-derived } \mathrm{CO}_{2}\end{array}$ & $\begin{array}{c}\text { Proportions of } \\
\text { L-derived } \mathrm{CO}_{2} \\
(\%)\end{array}$ & $\begin{array}{c}\text { Proportions of } \\
\text { S-derived } \mathrm{CO}_{2}\end{array}$ \\
\hline DHT & 3 & 32 & 65 \\
TJYC & 5 & 31 & 64 \\
HBLG & 2 & 36 & 62 \\
LHD & 15 & 23 & 62 \\
HET & 8 & 28 & 64 \\
SWZ & 2 & 33 & 65 \\
WFS & 2 & 34 & 64 \\
\hline
\end{tabular}

in the wells (correlation coefficient of 0.90 ; Table 2 and Figure 10), indicate that $\mathrm{CO}_{2}$ is mainly contributed by the microbial oxidation of organic matter in the sediments of the Tangshan fault zone. In particular, enriched $\mathrm{N}_{2}$ (93.65\% and $97.81 \%$, respectively) and depleted $\mathrm{O}_{2}$ $(0.45 \%$ and $4.55 \%$, respectively) were observed in soil gas wells LHD and HET (Table 2), which are located in the farmland. This should be attributed to the acceleration of nitrifying and denitrifying bacterial activity caused by artificial fertilization [51, 52].

The Tangshan fault zone is located in the well-known Bohai Bay sedimentary basin, where limestones are widely distributed in Ordovician, Cambrian, and Proterozoic strata in the deep earth $[30,53]$. These limestones could release 


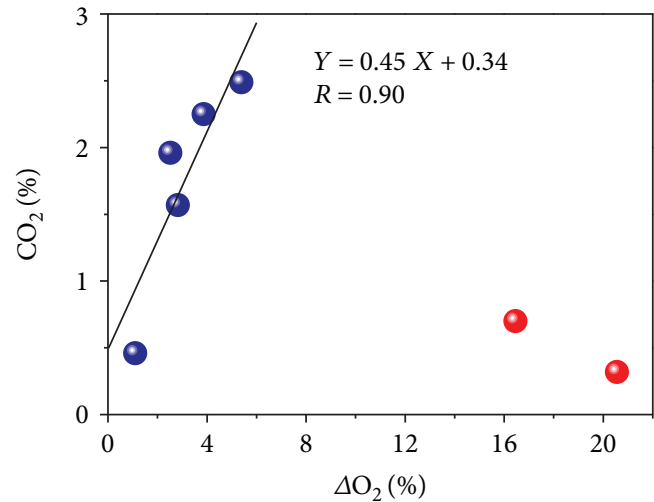

FIgURE 10: Relationship between depleted $\mathrm{O}_{2}$ concentrations (compared to atmosphere) and $\mathrm{CO}_{2}$ concentrations from the wells.

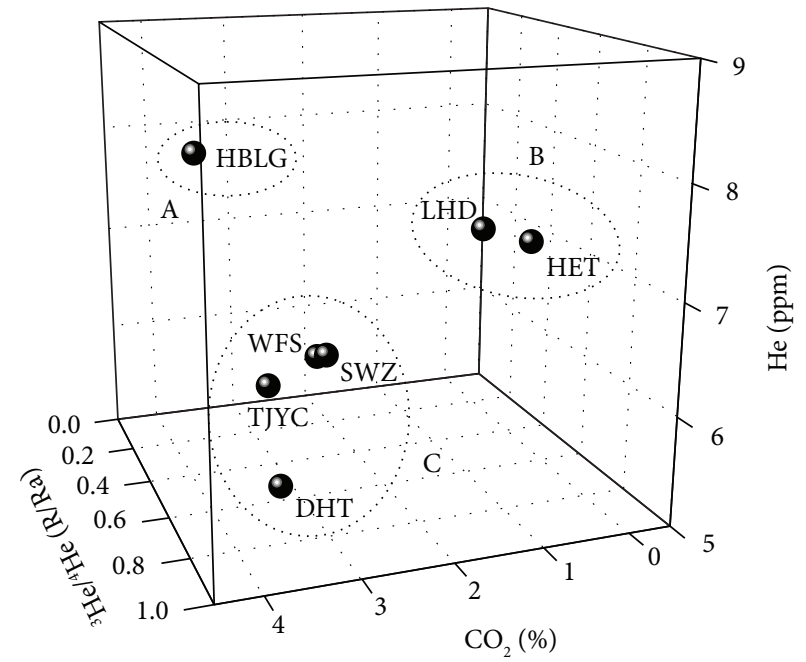

FIGURE 11: Relationship between ${ }^{3} \mathrm{He} /{ }^{4} \mathrm{He}$ and the average values of $\mathrm{CO}_{2}$ concentration and $\mathrm{He}$ concentration of soil gas. Red dots: values for wells DHT, HBLG, and WFS. Blue dots: values for wells TJYC, LHD, HET, and SWZ.

$\mathrm{CO}_{2}$ at high concentrations during its decomposition and reaction with groundwater and $\mathrm{CO}_{2}$, as per Eq. (2) [54-57].

$$
\begin{aligned}
\mathrm{CaCO}_{3}(\mathrm{~g}) & \longrightarrow \mathrm{CaO}(\mathrm{g})+\mathrm{CO}_{2}(\mathrm{~g}) \\
\mathrm{H}_{2} \mathrm{O}(\mathrm{l})+\mathrm{CO}_{2}(\mathrm{~g}) \uparrow & \longrightarrow \mathrm{H}_{2} \mathrm{CO}_{3}(\mathrm{aq}) \\
\mathrm{H}^{+}(\mathrm{aq})+\mathrm{CaCO}_{3}(\mathrm{~s}) & \longrightarrow \mathrm{Ca}^{2+}(\mathrm{aq}) \downarrow+\mathrm{HCO}_{3}{ }^{-}(\mathrm{aq}) \\
-\mathrm{HCO}_{3}{ }^{-}(\mathrm{aq})+\mathrm{H}^{+} & \longrightarrow \mathrm{H}_{2} \mathrm{O}(\mathrm{aq})+\mathrm{CO}_{2}(\mathrm{~g}) \uparrow
\end{aligned}
$$

Above all, it should be noted that the decomposition of carbonates in limestone strata could be another important potential source for the $\mathrm{CO}_{2}$ in the wells at the Tangshan fault zone.

In addition, it was shown in the relationship between ${ }^{3} \mathrm{He} /{ }^{4} \mathrm{He}$ and the average values of $\mathrm{CO}_{2}$ concentration and He concentration of soil gas from the seven soil gas wells that there were three distinguishing populations $(\mathrm{A}, \mathrm{B}$, and $\mathrm{C})$ for

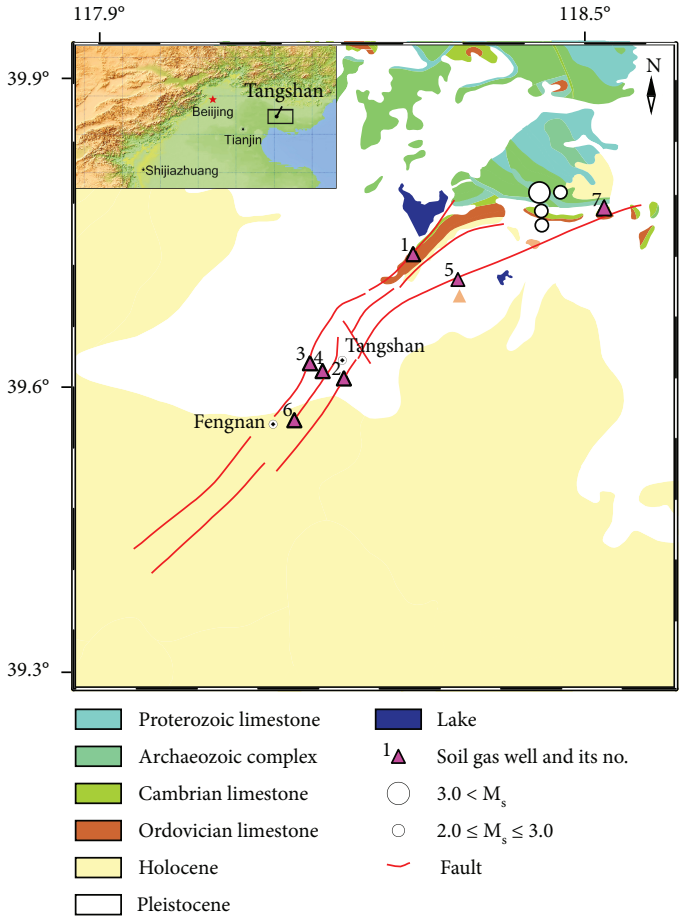

FIgURE 12: Locations of earthquakes in the Tangshan fault zone, August 5-19, 2018.

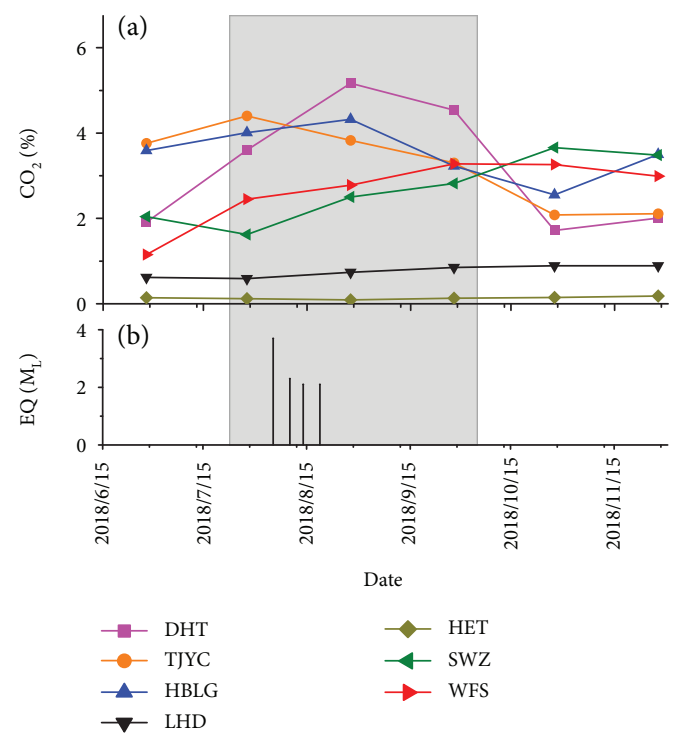

FIGURE 13: Relationship between earthquakes and soil gas chemical variations.

the seven soil gas wells (Figure 11). Population A included the soil gas well HBLG with relatively high $\mathrm{He}$ and $\mathrm{CO}_{2}$ concentrations, population $\mathrm{B}$ included the soil gas wells LHD and HET with relatively low $\mathrm{CO}_{2}$ concentration and medium $\mathrm{He}$ concentration, and population $\mathrm{C}$ included the soil gas wells TJYC, WFS, DHT, and SWZ with medium $\mathrm{CO}_{2}$ concentration and relatively low He concentration (Figure 11); 


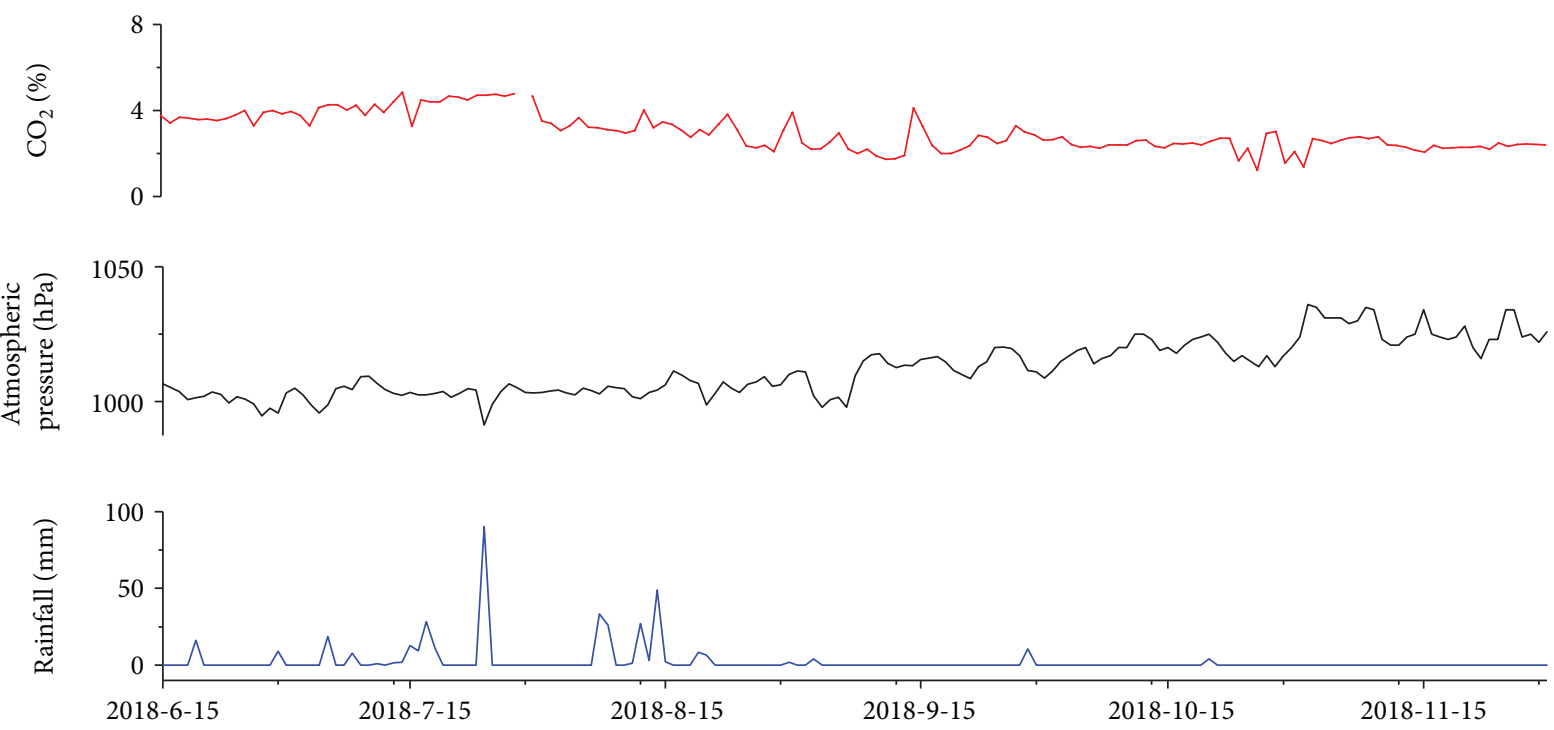

FIGURE 14: $\mathrm{CO}_{2}$ concentrations in soil gas from the TJYC well, atmospheric pressure, and local rainfall.

higher fractional contributions of L-derived $\mathrm{CO}_{2}$ is also present in TJYC, DHT, SWZ, and WFS wells, compared with LHD and HET wells, and with the highest one present in HBLG well (Table 4). Faults are preferred, and high-speed passage ways for uprising of gases from the deep earth [58], through which the escape of gases included in rocks of the deeper crust to the surface soil becomes relative easily $[4,59]$, and the gases migrating from the deeper earth usually have higher gas concentrations $[15,60]$. This indicated the deepest depth the fault cut downward and the most developed fractures in the segment where the HBLG well located, and the shallower depth the fault cut downward and the more developed fractures in the fault segments where the WFS, SWZ, TJYC, and DHT wells located $[8,61,62]$.

\subsection{Relationship between Earthquakes and Soil Gas Chemical} Variations. In the period August 5-19, 2018, a seismic sequence (four earthquakes of magnitude 2.0-4.0) struck the Guye region in the northern section of the Tangshan fault zone. The distances between the epicenter of the main shock $\left(M_{S} 3.7\right.$, focal depth $\left.=7 \mathrm{~km}\right)$ and the soil gas wells ranged between 6 and $45 \mathrm{~km}$ (Figure 12).

Abnormal soil gas signals related to earthquakes have been recognized in previous studies [7, 17, 63]. In this study, considerable variations in $\mathrm{CO}_{2}$ concentration were unexpectedly observed in the soil gas of the DHT, HBLG, TJYC, and WFS wells from July 28-September 28, 2018, during which time the seismic sequence occurred (Figure 13). Taking the mean values of $\mathrm{CO}_{2}$ concentration observed in June, October, and December 2018 as background values, the maximum increases in $\mathrm{CO}_{2}$ concentration were calculated to be $175 \%, 94 \%, 47 \%$, and $33 \%$ at the DHT, HBLG, TJYC, and WFS wells, respectively. These variations of the $\mathrm{CO}_{2}$ concentration were beyond the measurement error of the GXH 3010-E $\mathrm{CO}_{2}$ monitor, which is $\pm 2 \%$.
The time series data of $\mathrm{CO}_{2}$ concentrations in soil gas from the TJYC soil gas well, atmospheric pressure, and local rainfall from June 15, 2018, to December 15, 2018 are shown in Figure 14. It is indicated that the atmospheric pressure and rainfall have little impact on $\mathrm{CO}_{2}$ concentrations in soil gas from the TJYC soil gas well, which may be attributed to the significant depth at which the accumulation chamber had been fixed (5.0 $\mathrm{m}$ below the ground).

Therefore, the abnormal variations in soil gas $\mathrm{CO}_{2}$ concentration at wells DHT, HBLG, TJYC, and WFS could be responses to the seismic sequence. The peaks in $\mathrm{CO}_{2}$ concentration could be attributed to increased contributions of gas from underlying limestones as observed in different geological contexts [24,37].

\section{Conclusions}

The sources of soil gases in the Tangshan fault zone, North China, have been analyzed based on the soil gas chemical compositions and isotopic ratios obtained by measurement in the field and samples analysis in the laboratory.

The soil gases from the Tangshan fault zone were distinguished by three populations, based on the statistical analysis of $\mathrm{CO}_{2}$ concentration and $\mathrm{Rn}$ volume activity of soil gas collected at 388 sampling points using graphical statistical methods. Carbon dioxide of group (A) originates in the superficial soil while carbon dioxide of group (C) comes from deeper geological formations through faults. Carbon dioxide from group (B) could have a complex source, such as biogenic, thermogenic, mechanochemical, or be due to rock weathering.

Further information about the origin of soil gases was obtained according to the geochemical investigations of soil gases sampled in seven soil gas wells, drilled at the sites where group (C) soil gases had been observed. Soil gas compositions and isotopic ratios indicated that air (A) end-member, limestone (L) end-member, and sediment (S) end-member were 
identified as three major end-member components contributing to soil gas in the Tangshan fault zone; gas from the sediment (S) end-member was the primary source for the soil gases, and limestone (L) end-member was the secondary one.

The relationship between ${ }^{3} \mathrm{He} /{ }^{4} \mathrm{He}$ and the average values of $\mathrm{CO}_{2}$ concentration and $\mathrm{He}$ concentration of soil gas indicated the deepest depth the fault cut downward and the most developed fractures in fault segment were where the HBLG well was located and the shallower depth the fault cut downward and the more developed fractures in fault segments were where the WFS, SWZ, TJYC, and DHT wells were located.

Variations in $\mathrm{CO}_{2}$ concentration in the DHT, HBLG, and WFS wells observed in concomitance with a local seismic sequence confirm for the first time a possible contribution of carbon dioxide probably generated in underlying limestones.

\section{Data Availability}

The data for this paper are available in the text.

\section{Conflicts of Interest}

The authors declare that they have no conflicts of interest.

\section{Acknowledgments}

The authors are grateful to Prof. Liwu Li for analyzing the gas compositions and isotopic ratios (Institute of Geology and Geophysics, Chinese Academy of Sciences). This study is jointly supported by the Natural Science Foundation of China (Nos. 41573121, 41402298, and 41503114) and the Basic Science Research Plan of the Institute of Earthquake Science, China Earthquake Administration (Nos. 2016IES0102 and 2019IEF0703).

\section{References}

[1] Y. Y. Kagan and D. D. Jackson, "Earthquake forecasting in diverse tectonic zones of the globe," Pure and Applied Geophysics, vol. 167, no. 6-7, pp. 709-719, 2010.

[2] M. D. Zobak, "Seismology: Earthquake Forecasting and Warning," Science, vol. 222, no. 4621, p. 319, 1983.

[3] R. J. Zhou, R. C. Tang, Z. Z. Huang, Y. Lin, T. Yang, and W. Zhou, "Tectonic deformation and strong earthquake activities on the east border of Tibet Plateau," Earth Science Frontiers, vol. z1, pp. 297-298, 2000.

[4] G. Ciotoli, S. Lombardi, and A. Annunziatellis, "Geostatistical analysis of soil gas data in a high seismic intermontane basin: Fucino Plain, Central Italy," Journal of Geophysical Research, vol. 112, no. B5, article B05407, 2007.

[5] Z. Chen, Y. Li, Z. Liu, J. Wang, X. Zhou, and J. du, "Radon emission from soil gases in the active fault zones in the capital of China and its environmental effects," Scientific Reports, vol. 8, no. 1, 2018.

[6] T. Doğan, H. Sumino, K. Nagao, K. Notsu, M. K. Tuncer, and C. Çelik, "Adjacent releases of mantle helium and soil $\mathrm{CO}_{2}$ from active faults: Observations from the Marmara region of the North Anatolian Fault zone, Turkey," Geochemistry, Geophysics, Geosystems, vol. 10, no. 11, 2009.

[7] C. C. Fu, T. F. Yang, C. H. Chen et al., "Spatial and temporal anomalies of soil gas in northern Taiwan and its tectonic and seismic implications," Journal of Asian Earth Sciences, vol. 149, pp. 64-77, 2017.

[8] G. Ciotoli, G. Etiope, M. Guerra, and S. Lombardi, "The detection of concealed faults in the Ofanto Basin using the correlation between soil-gas fracture surveys," Tectonophysics, vol. 301, no. 3-4, pp. 321-332, 1999.

[9] F. Italiano, G. Martinelli, and P. Plescia, " $\mathrm{CO}_{2}$ degassing over seismic areas: the role of mechanochemical production at the study case of Central Apennines," Pure and Applied Geophysics, vol. 165, no. 1, pp. 75-94, 2008.

[10] C. Y. King, "Gas geochemistry applied to earthquake prediction: an overview," Journal of Geophysical Research Solid Earth, vol. 91, no. B12, pp. 12269-12281, 1986.

[11] A. Sciarra, B. Cantucci, and M. Coltorti, "Learning from soil gas change and isotopic signatures during 2012 Emilia seismic sequence," Scientific Reports, vol. 7, no. 1, 2017.

[12] G. Iovine, I. Guagliardi, C. Bruno et al., "Soil-gas radon anomalies in three study areas of Central-Northern Calabria (Southern Italy)," Natural Hazards, vol. 91, no. 1, pp. 193-219, 2018.

[13] J. L. Lewicki, W. C. Evans, G. E. Hilley, M. L. Sorey, J. D. Rogie, and S. L. Brantley, "Shallow soil $\mathrm{CO}_{2}$ flow along the San Andreas and Calaveras Faults, California," Journal of Geophysical Research: Solid Earth, vol. 108, no. B4, p. 2187, 2003.

[14] Y. Li, J. du, X. Wang, X. Zhou, C. Xie, and Y. Cui, "Spatial Variations of Soil Gas Geochemistry in the Tangshan Area of Northern China," Terrestrial, Atmospheric and Oceanic Sciences, vol. 24, no. 3, pp. 323-332, 2013.

[15] C. C. Fu, T. F. Yang, V. Walia et al., "Variations of soil-gas composition around the active Chihshang Fault in a plate suture zone, eastern Taiwan," Radiation Measurements, vol. 44, no. 9-10, pp. 940-944, 2008.

[16] J. P. Toutain and J. C. Baubron, "Gas geochemistry and seismotectonics: a review," Tectonophysics, vol. 304, no. 1-2, pp. 1-27, 1999.

[17] T. F. Yang, C. C. Fu, V. Walia et al., "Seismo-Geochemical Variations in SW Taiwan: Multi-Parameter Automatic Gas Monitoring Results," Pure and Applied Geophysics, vol. 163, no. 4, pp. 693-709, 2006.

[18] L. L. Chyi, T. J. Quick, T. F. Yang, and C. H. Chen, "The experimental investigation of soil gas radon migration mechanisms and its implication in earthquake forecast," Geofluids, vol. 10, no. 4, 563 pages, 2010.

[19] C. Y. King, "Radon emanation on San Andreas Fault," Nature, vol. 271, no. 5645, pp. 516-519, 1978.

[20] S. Džeroski, L. Todorovski, B. Zmazek, J. Vaupotic, and I. Kobal, "Modelling soil radon concentration for earthquake prediction," Discovery Science, vol. 2843, pp. 87-99, 2003.

[21] K. Kharatian, Y. Travi, and V. Igoumnov, "Activité du gaz radon dans l'air du sol et sismicité locale: exemple du bassin de l'Arax (Arménie)," Comptes Rendus Geoscience, vol. 334, no. 3, pp. 179-185, 2002.

[22] G. Chiodini, S. Caliro, C. Cardellini, R. Avino, D. Granieri, and A. Schmidt, "Carbon isotopic composition of soil $\mathrm{CO}_{2}$ efflux, a powerful method to discriminate different sources feeding soil $\mathrm{CO}_{2}$ degassing in volcanic-hydrothermal areas," Earth and Planetary Science Letters, vol. 274, no. 3-4, pp. 372-379, 2008. 
[23] M. C. Ray, D. R. Hilton, J. Muñoz, T. P. Fischer, and A. M. Shaw, "The effects of volatile recycling, degassing and crustal contamination on the helium and carbon geochemistry of hydrothermal fluids from the southern volcanic zone of Chile," Chemical Geology, vol. 266, no. 1-2, pp. 38-49, 2009.

[24] G. Yuce, C. C. Fu, W. D'Alessandro et al., "Geochemical characteristics of soil radon and carbon dioxide within the Dead Sea Fault and Karasu Fault in the Amik Basin (Hatay), Turkey," Chemical Geology, vol. 469, pp. 129-146, 2017.

[25] J. Heinicke, U. Koch, and G. Martinelli, " $\mathrm{CO}_{2}$ and radon measurements in the Vogtland Area (Germany) - A contribution to earthquake prediction research," Geophysical Research Letters, vol. 22, no. 7, pp. 771-774, 1995.

[26] V. S. Iakovleva and N. K. Ryzhakova, "Spatial and temporal variations of radon concentration in soil air," Radiation Measurements, vol. 36, no. 1-6, pp. 385-388, 2003.

[27] Q. LIU, J. WANG, J. CHEN, S. LI, and B. GUO, "Seismogenic tectonic environment of 1976 great Tangshan earthquake: results from dense seismic array observations," Earth Science Frontiers, vol. 14, no. 6, pp. 205-212, 2007.

[28] X. Wang, Y. Li, J. du, and X. Zhou, "Correlations between radon in soil gas and the activity of seismogenic faults in the Tangshan area, North China," Radiation Measurements, vol. 60, no. 1, pp. 8-14, 2014.

[29] W. Shen, Y. Fang, Q. Ni, Y. Lin, and Y. Liu, "Geochemical variation across the Cambrian-Ordovician boundary at Changshan section of Zhaogezhuang, Tangshan," Geological Journal of China Universities, vol. 2, no. 3, pp. 324-331, 1996.

[30] P. Feng, Tangshan engineering geological layer set in the key areas, Shijiazhuang University of Economics, Hebei, 2013, Master thesis.

[31] H. Guo, W. Jiang, and X. Xie, "Late-Quaternary strong earthquakes on the seismogenic fault of the $1976 M_{\mathrm{s}} 7.8$ Tangshan earthquake, Hebei, as revealed by drilling and trenching," Science China Earth Sciences, vol. 54, no. 11, pp. 1696-1715, 2011.

[32] J. Yang, Soil gas geochemistry characteristics in the capital area of China, Institute of Earthquake Forecasting, China Earthquake Administration, Beijing, 2018, Master thesis.

[33] S. R. Mei, C. H. Hu, C. Z. Zhu, J. Ma, Z. C. Zhang, and M. Y. Yang, The 1976 Tangshan Earthquake, Seismological Press, Beijing, 1982.

[34] N. Segovia, J. L. Seidel, and M. Monnin, "Variations of radon in soils induced by external factors," Journal of Radioanalytical and Nuclear Chemistry Letters, vol. 119, no. 3, pp. 199-209, 1987.

[35] W. Zhang, J. du, X. Zhou, and F. Wang, "Mantle volatiles in spring gases in the Basin and Range Province on the west of Beijing, China: constraints from helium and carbon isotopes," Journal of Volcanology and Geothermal Research, vol. 309, no. 1, pp. 45-52, 2016.

[36] A. J. Sinclair, "Selection of threshold values in geochemical data using probability graphs," Journal of Geochemical Exploration, vol. 3, no. 2, pp. 129-149, 1974.

[37] M. M. Parks, S. Caliro, G. Chiodini et al., "Distinguishing contributions to diffuse $\mathrm{CO} 2$ emissions in volcanic areas from magmatic degassing and thermal decarbonation using soil gas $222 \mathrm{Rn}-\delta 13 \mathrm{C}$ systematics: Application to Santorini volcano, Greece," Earth and Planetary Science Letters, vol. 377-378, pp. 180-190, 2013.

[38] R. Borgoni, V. Tritto, C. Bigliotto, and D. de Bartolo, "A geostatistical approach to assess the spatial association between indoor radon concentration, geological features and building characteristics: the case of Lombardy, northern Italy," International Journal of Environmental Research and Public Health, vol. 8, no. 5, pp. 1420-1440, 2011.

[39] G. Chiodini, R. Cioni, M. Guidi, B. Raco, and L. Marini, "Soil $\mathrm{CO}_{2}$ flux measurements in volcanic and geothermal areas," Applied Geochemistry, vol. 13, no. 5, pp. 543-552, 1998.

[40] V. Walia, S. J. Lin, C. C. Fu et al., "Soil-gas monitoring: a tool for fault delineation studies along Hsinhua Fault (Tainan), Southern Taiwan," Applied Geochemistry, vol. 25, no. 4, pp. 602-607, 2010.

[41] G. F. Birchard and W. F. Libby, "Soil radon concentration changes preceding and following four magnitude 4.2-4.7 earthquakes on the San Jacinto Fault in southern California," Journal of Geophysical Research, vol. 85, no. B6, pp. 31003106, 1980.

[42] G. Etiope and S. Lombardi, "Evidence for radon transport by carrier gas through faulted clays in Italy," Journal of Radioanalytical and Nuclear Chemistry Articles, vol. 193, no. 2, pp. 291300, 1995.

[43] Y. Yang, Y. Li, Z. Guan et al., "Correlations between the radon concentrations in soil gas and the activity of the Anninghe and the Zemuhe faults in Sichuan, southwestern of China," Applied Geochemistry, vol. 89, pp. 23-33, 2018.

[44] P. J. Hanson, N. T. Edwards, C. T. Garten, and J. A. Andrews, "Separating root and soil microbial contributions to soil respiration: a review of methods and observations," Biogeochemistry, vol. 48, no. 1, pp. 115-146, 2000.

[45] R. Ramnarine, C. Wagner-Riddle, K. E. Dunfield, and R. P. Voroney, "Contributions of carbonates to soil $\mathrm{CO}_{2}$ emissions," Canadian Journal of Soil Science, vol. 92, no. 4, pp. 599-607, 2012.

[46] C. Song, G. Han, N. Zhuo, and C. Q. Liu, "The characteristics and origin of $\mathrm{CO}_{2}$ in unsaturated zone at loess tableland of Northwestern China," Quaternary Sciences, vol. 37, no. 6, pp. 1172-1181, 2017.

[47] W. Gong, X. Yan, and J. Wang, "The effect of chemical fertilizer on soil organic carbon renewal and $\mathrm{CO}_{2}$ emission-a pot experiment with maize," Plant and Soil, vol. 353, no. 1-2, pp. 85-94, 2012.

[48] G. Tamir, M. Shenker, H. Heller, P. R. Bloom, P. Fine, and A. Bar-Tal, "Dissolution and Re-crystallization Processes of Active Calcium Carbonate in Soil Developed on Tufa," Soil Science Society of America Journal, vol. 76, no. 5, p. 1606, 2012.

[49] Y. Sano and B. Marty, "Origin of carbon in fumarolic gas from island arcs," Chemical Geology, vol. 119, no. 1-4, pp. 265-274, 1995.

[50] M. TAO, "Characteristics of mantle degassing and deepseated geological structures in different typical fault zones of China," Science in China Series D, vol. 48, no. 7, pp. 10741088, 2005.

[51] R. L. Mulvaney, S. A. Khan, and C. S. Mulvaney, "Nitrogen fertilizers promote denitrification," Biology and Fertility of Soils, vol. 24, no. 2, pp. 211-220, 1997.

[52] W. A. N. G. Jing, C. H. E. N. G. Yi, C. A. I. Zucong, and Z. H. A. N. G. Jinbo, "Effects of long-term fertilization on key processes of soil nitrogen cycling in agricultural soil: a review," Acta Pedologica Sinica, vol. 53, no. 2, pp. 292-304, 2016.

[53] X. M. Yu, C. G. Yang, G. M. Dong, and D. Zhan, "Drilling and completion technology in the first geothermal well 
construction in Jixian system in Tangshan," Exploration Engineering Media, vol. 41, no. 2, pp. 41-44, 2014.

[54] Z. Chen, Y. Li, C. G. Wang, and L. Yan, "Geochemical characteristics of water from mud volcano in the Wenquan County, Xinjiang," Earthquake Research in Sichuan, vol. 2, pp. 12-15, 2015.

[55] Z. Chen, Y. Li, Z. Liu et al., " $\mathrm{CH}_{4}$ and $\mathrm{CO}_{2}$ Emissions From Mud Volcanoes on the Southern Margin of the Junggar Basin, NW China: Origin, Output, and Relation to Regional Tectonics," Journal of Geophysical Research: Solid Earth, vol. 124, no. 5, pp. 5030-5044, 2019.

[56] P. Rovira and V. R. Vallejo, "Changes in $\delta^{13} \mathrm{C}$ composition of soil carbonates driven by organic matter decomposition in a Mediterranean climate: a field incubation experiment," Geoderma, vol. 144, no. 3-4, pp. 517-534, 2008.

[57] G. Tamir, M. Shenker, H. Heller, P. R. Bloom, P. Fine, and A. Bar-Tal, "Can soil carbonate dissolution lead to overestimation of soil respiration?," Soil Science Society of America Journal, vol. 75, no. 4, p. 1414, 2011.

[58] T. F. Yang, V. Walia, L. L. Chyi et al., "Variations of soil radon and thoron concentrations in a fault zone and prospective earthquakes in SW Taiwan," Radiation Measurements, vol. 40, no. 2-6, pp. 496-502, 2005.

[59] T. F. Yang, C. Y. Chou, C. H. Chen, L. L. Chyi, and J. H. Jiang, "Exhalation of radon and its carrier gases in SW Taiwan," Radiation Measurements, vol. 36, no. 1-6, pp. 425-429, 2003.

[60] M. H. Al-Tamimi and K. M. Abumurad, "Radon anomalies along faults in North of Jordan," Radiation Measurements, vol. 34, no. 1-6, pp. 397-400, 2001.

[61] C. E. Bond, Y. Kremer, G. Johnson et al., "The physical characteristics of a $\mathrm{CO}_{2}$ seeping fault: the implications of fracture permeability for carbon capture and storage integrity," International Journal of Greenhouse Gas Control, vol. 61, pp. 49-60, 2017.

[62] Y. Sun, X. Zhou, G. Zheng et al., "Carbon monoxide degassing from seismic fault zones in the Basin and Range Province, west of Beijing, China," Journal of Asian Earth Sciences, vol. 149, pp. 41-48, 2017.

[63] V. Walia, T. F. Yang, S. J. Lin et al., "Temporal variation of soil gas compositions for earthquake surveillance in Taiwan," Radiation Measurements, vol. 50, no. 2013, pp. 154-159, 2013. 

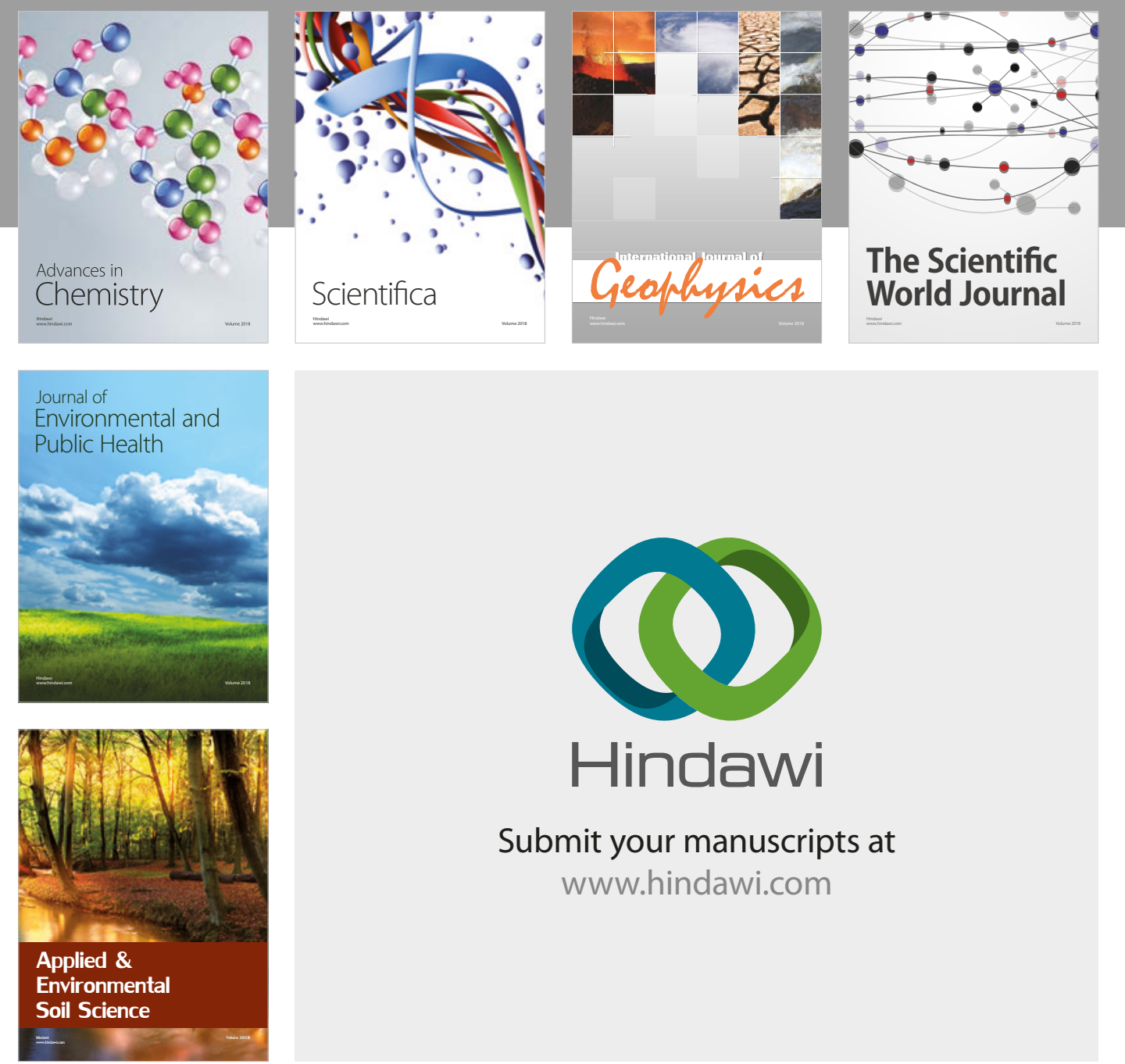

The Scientific

\section{World Journal}
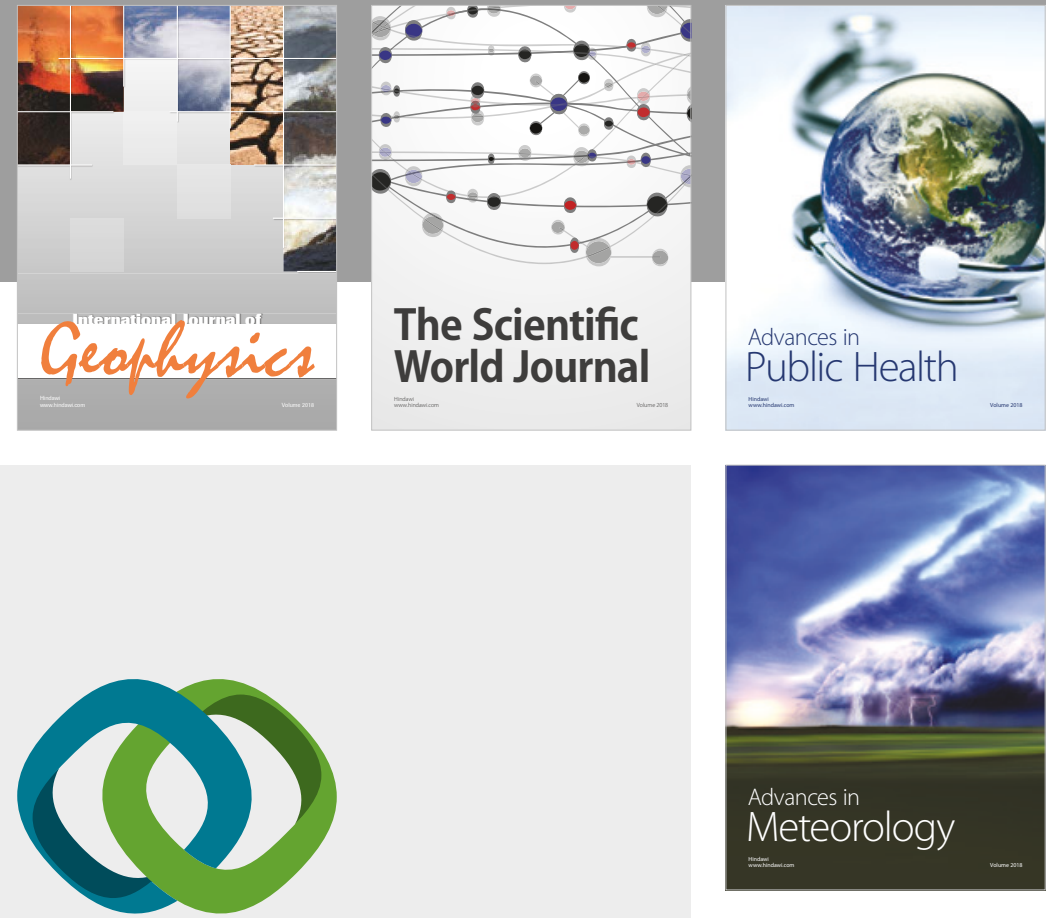

Advan

Public Health

\section{Hindawi}

Submit your manuscripts at

www.hindawi.com
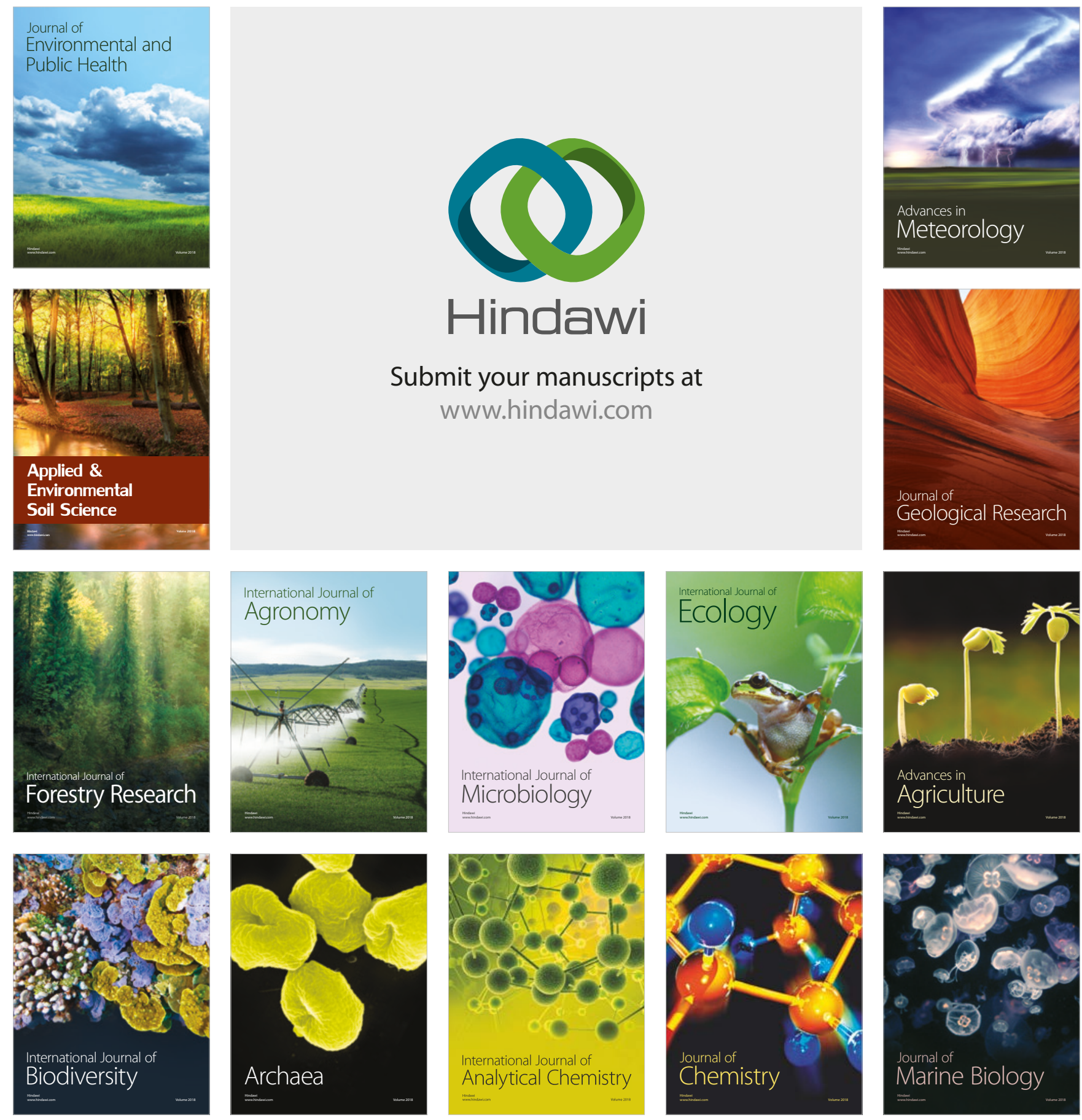